\title{
Correction to: Risky Gambling Behaviors: Associations with Mental Health and a History of Adverse Childhood Experiences (ACEs)
}

\author{
Lindsay A. Bristow ${ }^{1} \cdot$ Tracie O. Afifi $^{2}$. Samantha Salmon ${ }^{3} \cdot$ Laurence Y. Katz $^{4}$
}

Published online: 2 August 2021

(c) The Author(s) 2021

\section{Correction to: Journal of Gambling Studies https://doi.org/10.1007/s10899-021-10040-3}

The article "Risky Gambling Behaviors: Associations with Mental Health and a History of Adverse Childhood Experiences (ACEs)", written by Lindsay A. Bristow, Tracie O. Afifi, Samantha Salmon, Laurence Y. Katz, was originally published electronically on the publisher's internet portal on 23 June 2021 without open access. With the author(s)' decision to opt for Open Choice the copyright of the article changed on 7 July 2021 to (C) The Author(s) 2020 and the article is forthwith distributed under a Creative Commons Attribution 4.0 International License, which permits use, sharing, adaptation, distribution and reproduction in any medium or format, as long as you give appropriate credit to the original author(s) and the source, provide a link to the Creative Commons licence, and indicate if changes were made. The images or other third party material in this article are included in the article's Creative Commons licence, unless indicated otherwise in a credit line to the

The original article can be found online at https://doi.org/10.1007/s10899-021-10040-3.

Laurence Y. Katz

LKatz@hsc.mb.ca

Lindsay A. Bristow

umbristo@myumanitoba.ca

Tracie O. Afifi

Tracie.Afifi@umanitoba.ca

Samantha Salmon

samantha.salmon@umanitoba.ca

1 Max Rady College of Medicine, University of Manitoba, 727 McDermot Ave, Winnipeg, MB R3E 3P5, Canada

2 Departments of Community Health Sciences and Psychiatry, University of Manitoba, S113-750 Bannatyne Avenue, Winnipeg, MB R3E 0W5, Canada

3 Department of Community Health Sciences, University of Manitoba, 750 Bannatyne Ave, Winnipeg, MB R3E 0W3, Canada

4 Department of Psychiatry, University of Manitoba, PZ-162, 771 Bannatyne Ave, Winnipeg, MB R3E 3N4, Canada 
material. If material is not included in the article's Creative Commons licence and your intended use is not permitted by statutory regulation or exceeds the permitted use, you will need to obtain permission directly from the copyright holder. To view a copy of this licence, visit http://creativecommons.org/licenses/by/4.0.

The original article has been corrected.

Open Access This article is licensed under a Creative Commons Attribution 4.0 International License, which permits use, sharing, adaptation, distribution and reproduction in any medium or format, as long as you give appropriate credit to the original author(s) and the source, provide a link to the Creative Commons licence, and indicate if changes were made. The images or other third party material in this article are included in the article's Creative Commons licence, unless indicated otherwise in a credit line to the material. If material is not included in the article's Creative Commons licence and your intended use is not permitted by statutory regulation or exceeds the permitted use, you will need to obtain permission directly from the copyright holder. To view a copy of this licence, visit http://creativecommons.org/licenses/by/4.0/.

Publisher's Note Springer Nature remains neutral with regard to jurisdictional claims in published maps and institutional affiliations. 